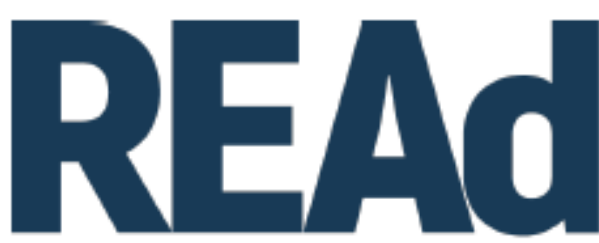

Revista Eletrônica de Administração

\title{
ETNOMETODOLOGIA E SEUS BASTIDORES NO BONS SONS: DESVENDANDO PERCURSOS $^{1}$
}

\section{Maria Luciana de Almeida ${ }^{2}$}

Lilian Soares Outtes Wanderley ${ }^{3}$

http://dx.doi.org/10.1590/1413-2311.296.101860

\section{RESUMO}

Nos estudos em administração existe um debate acerca do que as pessoas realmente fazem e/ou como fazem. Para entender o cotidiano é necessário vivenciar a realidade a fim de gerar interpretações a respeito do contexto de formação das práticas, o que remete ao uso da etnometodologia. Tendo em vista que existem poucas informações sobre o uso da etnometodologia enquanto método em pesquisas empíricas aplicadas no campo de estudos em administração este trabalho tem como objetivo dissertar sobre o percurso teóricometodológico adotado para construção de um estudo no campo da administração usando como base metodológica a etnometodologia. Para tanto, descreve-se os processos envoltos na realização de uma pesquisa aplicada focando na aproximação do campo e na construção do corpus e na interpretação dos construtos. Este estudo resultou em alguns aspectos relevantes, quais sejam: conexão local e pessoal, densidade da imersão, interpretação do cotidiano e transparência nas interações e identificação de pessoas chave.

Palavras-chave: Cotidiano. Práticas Sociais. Etnometodologia. Administração.

\section{ETHNOMETODOLOGY AND ITS BACKGROUNDS IN BONS SONS: DISCOVERING PATHWAYS}

In management studies there is a debate about what people actually do and / or how they do it.

\footnotetext{
${ }^{1}$ Recebido em 10/4/2020, aceito em 21/10/2020.

${ }^{2}$ Universidade de Pernambuco -Mata Norte, PE (Brasil); http://orcid.org/0000-0003-3551-5904; lucianalmeida.pe@gmail.com.

${ }^{3}$ Universidade Federal de Pernambuco. Departamento de Ciências Administrativas - Recife, PE (Brasil); http://orcid.org/0000-0002-8608-2750; lilian.wanderley@ufpe.br.

(c) (1) $(2)$ REAd | Porto Alegre - Vol. 26 - N. 3 - Setembro / Dezembro 2020 - p. 586-619.
} 
In order to understand everyday life, it is necessary to experience reality in order to generate interpretations regarding the context of the formation of practices, which refers to the use of ethnomethodology. Bearing in mind that there is little information on the use of ethnomethodology as a method in empirical research applied in the field of studies in administration, this work aims to discuss the theoretical and methodological path adopted to build a study in the field of administration using as a methodological basis ethnomethodology. To this end, the processes involved in carrying out applied research focusing on the approach of the field and the construction of the corpus and the interpretation of constructs are described. This study resulted in some relevant aspects, namely: local and personal connection, density of immersion, interpretation of daily life and transparency in interactions and identification of key people.

Keywords: Daily life. Social Practices. Ethnomethodology. Administration.

\section{ETNOMETODOLOGÍA Y SUS BASTIDORES EN EL BONS SONS: DESCUBRIENDO CAMINOS}

En los estudios de gestión hay un debate sobre lo que las personas realmente hacen y / o cómo lo hacen. Para comprender la vida cotidiana, es necesario experimentar la realidad para generar interpretaciones sobre el contexto de la formación de prácticas, que se refiere al uso de la etnometodología. Teniendo en cuenta que hay poca información sobre el uso de la etnometodología como método en la investigación empírica aplicada en el campo de los estudios en administración, este trabajo tiene como objetivo discutir el camino teórico y metodológico adoptado para construir un estudio en el campo de la administración utilizando como base metodológica Etnometodología. Con este fin, se describen los procesos involucrados en la realización de investigación aplicada centrada en el enfoque del campo y la construcción del corpus y la interpretación de los constructos. Este estudio resultó en algunos aspectos relevantes, a saber: conexión local y personal, densidad de inmersión, interpretación de la vida diaria y transparencia en las interacciones e identificación de personas clave.

Palabras clave: Vida Cotidiana. Prácticas sociales. Etnometodología. Administración.

\section{INTRODUÇÃO}

Nos estudos em administração existe um debate acerca do que as pessoas realmente fazem e/ou como fazem. Na verdade, esta discussão vem desde os primórdios com a emergência da teoria das relações humanas e as abordagens comportamentais. Se pensarmos 
sobre a evolução do pensamento administrativo observamos que passados alguns anos as premissas da administração científica e clássica passaram a demandar novos estudos a respeito da produtividade nas organizações. Se o foco inicialmente foi posto na tarefa e no processo administrativo, administração científica e teoria clássica, respectivamente, o fator humano emergiu como determinante em seguida. A experiência de Hawthorne, principal expressão empírica da teoria das relações humanas, ao analisar a influência da luminosidade na produtividade, evidenciou que o fator humano é determinante nos resultados.

Por meio desta experiência foi possível entender que as pessoas agem, não apenas de acordo com as determinações de seus superiores e de manuais e guias, elas são influenciadas pelo meio que as circundam. Este cenário abriu caminho para os estudos comportamentais nas organizações, os quais mostram a complexidade das pessoas, sendo imperativo às organizações entender necessidades individuais e buscar estratégias organizacionais que englobem, também, as demandas individuais. Ou seja, para alcançar os objetivos organizacionais é fundamental que as pessoas envolvidas alcancem seus objetivos individuais. Alguns estudos se focaram nos gerentes e líderes e buscaram evidenciar o que eles de fato fazem em seu cotidiano (KOTTER, 1990, 1999) e discorrer sobre a natureza do trabalho gerencial e os papéis que os gestores organizacionais desempenham (MINTZBERG, 1973).

Os estudos organizacionais seguiram perpassando pela formação das ordens sociais e, portanto, pelo cotidiano, ou seja, pelas ações diárias das pessoas nas organizações. Nas décadas de 1990 e 2000 muitos são os estudos desenvolvidos com campo da aprendizagem nas organizações (ANTONACOPOULO, 2006; BROWN; DUGUID, 1991; CANDY, 1991; EASTERBY-SMITH; BURGOYNE; ARAUJO，2001; EASTERBY-SMITH; CROSSAN; NICOLINI, 2000; EASTERBY-SMITH; SNELL; GHERARDI, 1998; ELKJAER, 2004, 2009; FENWICK, 2001，2008; GHERARDI; NICOLINI; ODELLA， 1998; LAVE; WENGER, 1991; MERRIAM; CAFFARELLA; BAUMGARTNER, 2007; MEZIROW, 1991, 1994; MIETTINEN, 2000). A aprendizagem tomava um amplo espaço nas pesquisas, pois, como evidenciaram as teorias comportamentais as pessoas são complexas e significam suas vivências organizacionais de formas diversas. Além disso, existe a necessidade de socialização de conhecimentos tácitos, a disputa de capital intelectual e a necessidade de entender a relação entre o individual e o organizacional.

Este interesse pelo o que e como as pessoas aprendem acaba alcançando a área de estratégia. Conforme Whittington (1996) as pesquisas neste campo geralmente supunham a estratégia como algo que as organizações possuem, colocando o papel das pessoas, no 
desenvolvimento dela, em segundo plano, por isso ele propõe uma nova abordagem denominada "estratégia como prática". A estratégia como prática surge tendo por base os estudos das teorias da prática (SCHATZKI; CETINA; SAVIGNY, 2001) e coloca o foco nos atores sociais, ao buscar entender como a estratégia é realizada pelas pessoas (WHITTINGTON, 1996). Sob a ótica desta perspectiva a estratégia não é algo que as organizações possuem ou fazem e sim algo que seus membros realizam (JOHNSON et al., 2007), aqui o enfoque é no papel das pessoas enquanto estrategistas (JARZABKOWSKI; SPEE, 2009).

Mais recentemente, na década de 2010, é a vez do campo de estudos em sustentabilidade partir para beber na fonte das teorias da prática (SHOVE, 2010, 2012, 2012a, 2012b; SHOVE; PANTZAR; WATSON, 2012; CHAPPELLS; MEDD; SHOVE, 2013). Estes estudos defendem que a sustentabilidade se mostra viável a partir do momento em que as pessoas a adotam cotidianamente, tornando-a uma prática social, ou seja, algo que elas se engajam de modo que se torne habitual. Entendendo que o processo para internalizar atividades visando transformar a sustentabilidade em uma prática social é amplo e complexo, visto que este é constituído por discursos legitimados coletivamente, o que os estudos empreendidos pela Shove (2012, 2012a, 2012b) e seus associados propõem é que se mude de foco. Neste sentido, ao invés de focalizar o indivíduo e suas escolhas individuais, a proposta é tentar compreender como as práticas se disseminam e conquistam adeptos que as promulgam rotineiramente (SHOVE; PANTZAR e WATSON, 2012).

Com tantos estudos dentro do campo dos estudos em administração enfocando as teorias da prática como desenvolver estas investigações do ponto de vista metodológico? Para entender cotidiano é necessário vivenciar a realidade a fim de gerar interpretações a respeito do contexto de formação das práticas. Assim, é interessante lançar mão da experiência dos estudos etnográficos. Sobretudo, ao entendermos que a antropologia não se debruça mais, apenas, por um objeto especial (“os primitivos”), investigando todas as classes de fenômenos e a cultura não é mais um tópico exclusivo deste campo teórico (CLIFFORD, 2002). Neste contexto a etnometodologia emerge como uma alternativa ao permitir usar as bases etnográficas tendo como foco as práticas sem para tanto se apropriar da alcunha de antropólogo.

Tendo em vista que existem poucas informações sobre o uso da etnometodologia enquanto método em pesquisas empíricas aplicadas no campo de estudos em administração este trabalho tem como objetivo dissertar sobre o percurso teórico-metodológico adotado para 
construção de um estudo no campo da administração usando como base metodológica a etnometodologia. Para tanto se usa como exemplo uma pesquisa desenvolvida para consecução de uma tese de doutorado que teve como segmento empírico um festival de música portuguesa.

Devido à natureza do trabalho, a qual envolve alto grau de pessoalidade, que permite a autoria colocar "sentimentos e reações pessoais de sua vivência em campo diretamente no texto" (KOTTAK, 1997, p. 27), o texto etnometodológico é, primordialmente, escrito em primeira pessoa do singular. Neste caso parte do texto será escrito na primeira pessoa do singular devido ao compartilhamento da vivência que permitiu a imersão na comunidade para realização do estudo.

\section{ETNOMETODOLOGIA: CONCEITOS BÁSICOS}

A etnometodologia é um termo criado por Garfinkel a partir da década de 1950, período em que ele estava em processo de doutoramento na universidade de Harvard, que traz uma nova perspectiva para análise da sociedade (OLIVEIRA; MONTENEGRO, 2012). A etnometodologia não foge do estudo de temas fundamentais na sociologia, quais sejam, ação social, intersubjetividade e constituição social do conhecimento, mas os coloca sob uma nova ótica de percepção (HERITAGE, 1999). Os estudos tradicionais focavam em fatores motivacionais e/ou questões extraordinárias enquanto Garfinkel passa a enfocar a cognoscibilidade dos atores em seu contexto cotidiano. Neste sentido, os estudos etnometodológicos reconhecem a capacidade reflexiva e interpretativa dos atores sociais, havendo, assim, uma mudança do paradigma normativo para o interpretativo (COULON, 1995). Conforme Coulon (1995, p.13) para os etnometodólogos “[...] a relação entre ator e situação não está baseada em conteúdos culturais nem em regras, mas nasce a partir de processos de interpretação".

A etnometodologia surgiu a partir de investigações empreendidas por estudiosos descontentes com os rumos dos estudos sociológicos, os quais passaram a defender que a ciência da sociologia deveria ter como essência e finalidade a promoção da investigação do cotidiano. Os estudos etnometodológicos "analisam as atividades cotidianas como métodos que seus membros usam para fazer com que estas atividades sejam racionalmente-visíveis-ereportáveis-para-todos-os-fins-práticos, isto é, 'explicáveis' (accountable) [...]" (GARFINKEL, 2006, p. 1). Desse modo, as atividades são desenvolvidas de modo que seja possível relatar aos demais seres humanos, resultando em um processo socialmente construído 
(BERGER; LUCKMAN, 1967) no tempo e no espaço (GIDDENS, 2009). Não se busca gerar descrições ou prescrições a respeito do processo de construção da realidade, o que se pretende é apenas interpretá-lo.

Ao romper com o paradigma normativo e passar a entender a sociedade por meio da interpretação, os estudos etnometodológicos o fazem adotando conceitos já existentes, mesmo no contexto normativo. A etnometodologia traz muitos conceitos de outras correntes de estudo, mas faz acréscimos, adaptações ou modificações nos mesmos (GUESSER, 2003). Entretanto, "o que mais chama a atenção na etnometodologia é o caráter complementar e solidário de seus conceitos" (COULON, 1995, p.31). Garfinkel deu vida a muitos conceitos em sua obra. Conforme Coulon (1995), os mais importantes e acessíveis aos interessados em se aventurar em fazer investigações pautadas pela etnometodologia são: prática/realizações; indexicalidade; reflexividade; relatabilidade (accountability); e noção de membro.

\section{Prática/realizações}

Os estudos etnometodológicos se concentram nas realizações práticas dos indivíduos. De acordo com Heritage (1999, p. 331), Garfinkel estabeleceu um novo foco para os estudiosos que almejassem empreender esforços voltados aà análise sociológica: "o estudo das propriedades do senso comum nas situações mundanas de ação”. Sendo assim, o fio condutor dos estudos desenvolvidos por ele são "as atividades práticas, em particular as razões práticas, sejam estas profissionais ou profanas" (COULON, 1995, p. 32). As realizações sociais são empreendidas pelos indivíduos que atuam constituindo a sociedade (GARFINKEL; SACKS, 1986), sejam estes cientistas ou não, pois, não importa a base de seus conhecimentos, eles atuam socialmente de modo a adaptarem as regras sociais e construírem interpretativamente a sociedade.

Em uma conceituação simples, práticas são entendidas como atividades humanas organizadas (SCHATZKI, 2003, 2005). Contudo, esta organização das atividades humanas envolve uma complexidade de fenômenos. Assim, qualquer prática é constituída por um conjunto aberto de ações organizadas espaço-temporalmente. E, por isso, essa aparente aproximação com o conceito de realizações.

Desse modo, a análise etnometodológica se baseia em "escolher entre as estruturas de significação [...] e determinar sua base social e sua importância” (GEERTZ, 2008, p. 7). Os resultados de investigações desta natureza expressam como membros de uma determinada coletividade, em certo tempo e em um espaço específico, atuam, por meio de um sistema ordenado de atividades, construindo, reconstruindo, modificando, de modo a perpetuar ou 
extinguir as práticas (BISPO; GODOY, 2014). Neste sentido, estudos desta natureza têm como foco identificar e compreender o fluxo de atividade de uma coletividade a fim de entender como os atores constituem as práticas que ordenam a vida social (BISPO; GODOY, 2014).

\section{Indexicalidade}

Os atores sociais estão em constante interpretação da sociedade, utilizando seus entendimentos para modificarem, atualizarem e adaptarem o mundo social, ou seja, construindo espaço temporalmente o mundo em que vivem. Este processo de construção só é possível por meio da linguagem. A linguagem é a forma por meio da qual compartilhamos significados, nos fazemos entender ao utilizar uma língua em comum. Estudiosos da linguagem e da filosofia, como Schutz, Wittgenstein, Peirce e Bar-Hillel, já discutiam as propriedades da linguagem (FIRTH, 2010) sinalizando que esta possui aspectos indexicais. Tomando por base estes estudos Garfinkel e Sacks (1986) advogam que as formas linguísticas são indexicais em sua totalidade e que esta indexicalidade é inerente à língua e, portanto, irreparável.

Ao desenvolver alguns experimentos, Garfinkel (2006) evidencia que aspectos contextuais influenciam na interpretação da fala dos indivíduos. Desse modo, se reproduzirmos um diálogo entre um casal de namorados ou entre um grupo de amigos, ou mesmo de uma reunião de trabalho fora do contexto em que este aconteceu não conseguiremos entender muito do que está sendo dito. Isto ocorre porque a linguagem é indexical, assim, saberemos o significado geral das palavras, mas não teremos dados contextuais que influenciam significativamente no entendimento, visto que as palavras ganham significações diversas a depender de quem a pronuncie, bem como, do momento e do lugar em que for pronunciada.

\section{Reflexividade}

Os sociólogos tradicionais defendiam que os atores agem tomando por base norteadora as normas sociais, sendo estas direcionadoras de comportamento. Os etnometodólogos não negam as normas, mas argumentam que estas são apenas uma das partes constituintes do contexto que serve de base às ações sociais. Conforme expressa Heritage (1999) a contextualidade das ações é fundamental para entendermos as próprias ações. A respeito do caráter problemático de ações práticas "os membros tomam como dado que um membro deve, desde o início, "conhecer" as situações nas quais ele deve operar, caso suas práticas devam servir de medida para transformar as características específicas e localizadas dessas situações 
em um relato reconhecível” (GARFINKEL, 2006, p. 17). Neste sentido, os atores sociais agem tendo como pressuposto informações contextuais.

Em alguns experimentos (para mais informações ver Garfinkel, 2006) realizados por Garfinkel é possível perceber a atuação da reflexividade nas conversações desenvolvidas pelos atores. Ao estudar uma conversar entre um casal Garfinkel nos mostra que eles interagem tendo por base uma gama de informações contextuais. Este experimento possibilitou a percepção de que a interpretação das expressões emitidas pelo 'outro' ocorre tendo como referencial o lugar que este 'outro' ocupa no contexto de ordem social estabelecida (HERITAGE, 1999). Em outro experimento, estudantes foram levados a descreverem suas famílias, sendo suprimidas as ligações biográficas, ou seja, descrevê-las como se as pessoas não tivessem uma ligação pessoal consigo. O resultado mostrou que conflitos, rixas e outras características não relacionadas a noção de família estabelecida emergiram. Assim, a supressão de pressupostos contextuais pode alterar drasticamente a percepção e o relato de uma realidade (HERITAGE, 1999).

Neste sentido, entende-se que os atores não agem simplesmente como reprodutores de normas, sendo as ações realizadas de modo reflexivo. Assim, ao agirem, os atores têm por base o contexto e atuam reconstruindo o mesmo contexto, sendo, portanto, constituídos no contexto e constituintes do contexto, ou seja, inteligíveis nele e responsáveis por ele (FIRTH, 2010; COULON, 1995). Assim, os atores são dotados de um repertório de entendimentos que são levados em consideração nas interações sociais.

\section{Relatabilidade (Accountability)}

Já no prólogo do livro estudos em etnometodologia, Garfinkel (2006) explica que as investigações etnometodológicas analisam o fluxo de atividades cotidianas visando evidenciar os métodos utilizados pelos atores para torná-lo explicável, ou seja, relatável. Os atores agem construindo a realidade social, neste sentido, as ações exprimem o mundo social. A relatabilidade é a "propriedade que permite que os atores tornem o mundo visível a partir de suas ações, tornando as ações compreensíveis e transmissíveis", pois, "ao passo que são dotadas de significado e sentido através dos processos pelos quais são relatadas, as ações sociais exprimem o mundo social na sua mais pura essência" (GUESSER, 2003, p. 162). É possível inferir que a relatabilidade é o processo que permite o compartilhamento de significados de ações de modo reflexivo e racional.

Não basta executar atividades, estas precisam ser expostas, visto que é por meio desta construção que o mundo social é constituído. "Fazer visível o mundo é fazer compreensível 
minha ação ao descrevê-la, porque dou a entender seu sentido ao revelar os procedimentos que emprego para expressá-la” (COULON, 1995, p. 49). A sociedade se constrói a partir do fluxo de ações executadas espaçotemporalmente. A relatabilidade permite que esta construção seja compreendida, por conseguinte, vemos o mundo por meio dos relatos de nossas ações.

\section{Noção de Membro}

Os estudos etnometodológicos trazem uma nova concepção para a noção de membro, sendo esta uma questão chave para o entendimento da etnometodologia. Conforme Garfinkel em entrevista concedida a Jules-Rosette (1985): “[...] alguns sociólogos insistem [...] que se deve conceber os membros como se fossem entidades coletivamente organizados. Rejeitamos em absoluto essa alegação. Para nós, as 'pessoas', 'pessoas particulares' e 'indivíduos' são aspectos observáveis de atividades cotidianas”. Garfinkel e Sacks (1986) trazem a noção de membro como cerne da concepção etnometodológica. Para eles, o termo membro não se refere a uma pessoa, mas ao domínio de uma linguagem comum. As pessoas usam uma linguagem comum a fim de transformar expressões indexicais em expressões objetivas. Ao falarem os indivíduos atuam produzindo e expondo objetivamente o conhecimento do senso comum de atividades cotidianas, tornando-as "fenômenos observáveis e relatáveis" (GARFINKEL; SACKS, 1986, p. 227). O membro é entendido, não como uma pessoa que se organiza coletivamente, mas, como alguém que se utiliza da linguagem, a fim se fazer compreendido, o que, por conseguinte, resulta na possibilidade de atuação de modo que o conhecimento seja observável e relatável, constituindo, assim, as práticas.

\section{CAMPO EMPÍRICO: PERCURSO ETNOMETODOLÓGICO}

Os estudos em etnometodologia possuem como foco de interesse as estruturas formais das atividades cotidianas (GARFINKEL; SACKS, 1986). Conforme Guesser (2003) os etnometodólogos concentram seus esforços investigativos no raciocínio prático do cotidiano, tendo como finalidade construir, a partir deste, explicações para a realidade observada. É válido elucidar que tais explicações não suportam contextos de análise abrangentes, e, por conseguinte, não podem ser extrapoladas para realidades totalizantes. As explicações (re)construídas pelas evidências encontradas no raciocínio prático cotidiano dão conta apenas de "significações interacionais de um determinado grupo, em determinado contexto histórico e cultural" (GUESSER, 2003, p. 163). Neste sentido, as investigações etnometodológicas fornecem explicações para contextos situados, ou seja, cenários socioculturais específicos nos quais se processam interações gerando significados. 
Entretanto, apesar de ter um foco 'estreito', no sentido de não abarcar, como mote de análise, realidades totalizantes, a etnometodologia proposta por Garfinkel não possui, como tema de investigação, questões individuais. Em seus estudos Garfinkel evidencia sua crença de que interesses e/ou atitudes individuais não possuem relevância, no concernente as ordens situadas (RAWLS, 2008). Conforme expresso por Oliveira e Montenegro (2012, p. 139), a preocupação de Garfinkel "é com as maneiras padronizadas nas quais as propriedades de ordem da ação situada tornam-se públicas". Tal fato se justifica, visto que não são as motivações particulares que dotam os ordenamentos sociais de significado. $\mathrm{Na}$ verdade, as ações que constituem as ordens sociais possuem significado independente de questões individuais (RAWLS, 2008) e os estudos etnometodológicos buscam descrever como tais ordens sociais se tornam aparente espaço-temporalmente.

A etnometodologia busca entender como os atores percebem, interpretam e significam o mundo, bem como, como as regras formais atuam governando as interações entre estes. A sociologia tradicional defendia que a interiorização de regras estabelecidas leva a modos de ação automáticos e irrefletidos que seriam reproduzidos socialmente. Os etnometodólogos não acreditam nesta colocação, argumentando que as ações dos indivíduos não são balizadas pela posição social ocupada por eles (COULON, 1995).

A fim de se aproximar da realidade social, buscando entender como as interações ocorrem de maneira a (re)construir a sociedade, os estudos em etnometodologia trouxeram da fenomenologia o conceito de suspensão. Como afirma Oliveira e Montenegro (2012, p. 133) “a colocação entre parênteses (a suspensão e não a negação) das teorias sobre o mundo social possibilita ao observador-pesquisador aproximar-se daquilo que os próprios membros da vida cotidiana produzem interpretativamente e reconhecem como realidade". Seguindo o conceito de suspensão, as investigações etnometodológicas devem ser pautadas por uma busca pelo entendimento da realidade prática dos atores sem concepções apriorísticas.

O pesquisador deve ir a campo sem questões pré-formuladas, roteiros estruturados ou qualquer outro instrumento que direcione a coleta de dados para fins estabelecidos (RAWLS, 2008). Segundo Bispo e Godoy (2014) a ideia é buscar compreender como os atores estudados tornam algo inteligível, ou seja, quais os métodos que estes utilizam para interpretar e significar as atividades. Assim, os etnometodólogos devem conduzir suas investigações sem preconcepções, tendo em vista o alcance do entendimento do cerne das práticas cotidianas, isto é, de como elas realmente são construídas, bem como, de qual significação é atribuída às mesmas. Desse modo, "a principal preocupação do pesquisador ao ir a campo deve ser a do 
exercício da observação e compreensão de como os membros de um grupo agem a partir do seu ponto de vista, apoiando-se nas referências sociais que possuem" (BISPO; GODOY, 2014, p. 117). Garfinkel chama este processo de indiferença etnometodológica.

\footnotetext{
Os estudos etnometodológicos de estruturas formais estão voltados para o estudo de tais fenômenos, buscando descrever os relatos dos membros a respeito de estruturas formais onde quer e por quem quer que sejam feitos, ao mesmo tempo em que se abstêm de qualquer julgamento quanto à sua adequação, valor, importância, necessidade, praticidade, sucesso ou consequencialidade. Chamamos a essa política de procedimento de "indiferença etnometodológica" (GARFIKEL; SACKS, 1986, p. $165)$.
}

A aproximação da realidade na etnometodologia se dá por meio do entendimento do conhecimento do senso comum e das práticas dos atores sociais. Nos estudos de natureza etnometodológica, os especialistas na temática em investigação são os atores sociais envoltos no âmbito da pesquisa e não o pesquisador, portanto, este não pode observar o fenômeno sob uma lente dotada de pressupostos preestabelecidos (BISPO; GODOY, 2014). Tendo em vista que "a Etnometodologia tem por finalidade mostrar os meios empregados pelos membros para organizar a vida social comum, a primeira tarefa de uma estratégia de investigação é descobrir o que fazem os membros" (COULON, 1995, p. 93-94). Neste sentido, tratam-se os atores participantes do estudo como experts porque a etnometodologia enfoca o entendimento da ordem vivida em um agrupamento, sendo este obtido por meio da alteração, criação e recriação das práticas (FRANCIS; HESTER, 2004).

No estudo tomado como base, a ida a campo se deu sem preconceitos ou concepções apriorísticas que amarrassem previamente a interpretação, mas não foi possível (e não acho que seja possível fazê-lo) nos despir das nossas concepções de vida e conceituais. Por mais que seja necessário manter um distanciamento da realidade estudada, a interpretação é balizada pela cognoscitividade e pela intersubjetividade. Conforme argumenta Clifford (2002, p. 43), "nem a experiência nem a atividade interpretativa do pesquisador científico podem ser consideradas inocentes", isso porque qualquer interpretação envolverá algum nível de subjetividade. Assim, o processo deve ser considerado não como uma "interpretação de uma 'outra' realidade circunscrita, mas sim como uma negociação construtiva envolvendo pelo menos dois, e muitas vezes mais, sujeitos conscientes e politicamente significativos".

Apesar de muitos estudos apresentarem etapas a serem cumpridas, quando nos propomos a realizar um estudo lançando mão de princípios etnográficos, em geral, não é possível desenvolver a investigação de maneira linear. Muitas vezes o que se almeja encontrar só é percebido quando da finalização do estudo ou não é encontrado e o foco muda de modo que seja dada a ênfase necessária ao que emergir do campo (SILVA, 2000). Algumas 
concepções podem surgir antes da imersão e outras só tempos depois da saída de campo. É um jogo constante e aproximação e distanciamento (CLIFFORD, 2002).

Por isso foi preciso entender qual era a realidade antes da imersão, mas evitando conceber análises de qualquer natureza, o conhecimento obtido a priori foi necessário para a aproximação do campo. Não foram concebidos instrumentos, roteiros ou questões estruturadas que pudessem ditar o caminho, todo o processo de imersão se deu de forma orgânica e foram os atores envoltos que ditaram o ritmo da investigação. Houve momentos de maior interação e espontaneidade e momentos de estranhamento e um pouco de desconfiança, a exemplo de uma conversa descontraída durante um concerto na qual um dos atores investigados falou rindo: "sinto que estou sendo observado", ao se referir a minha presença.

Tendo em vista a necessidade de aproximação do campo empírico comecei a refletir sobre a melhor forma de me inserir no festival. Será que ir apenas como festivaleira me proporcionaria às informações necessárias à compreensão da concepção e organização do evento? Provavelmente não, por isso, busquei informações no site do festival e descobri que eu poderia me inscrever para participar de uma seleção de voluntários para trabalhar no festival. Inscrevi-me e fiz uma entrevista de quase vinte minutos por Skype com um dos organizadores do evento. Na ocasião deixei claro que gostaria de participar como voluntária na função que fosse requerida, mas, que tinha como principal interesse o desenvolvimento de um estudo de natureza acadêmica que constituiria minha tese de doutorado.

Este foi o meu primeiro contato com o campo, exceto pelas informações exibidas no site do festival. O entrevistador me falou sobre a concepção comunitária do evento, explicou que os voluntários eram parte essencial na organização do festival e que a ideia é realmente vivenciar o espaço como um todo e não apenas ir a um festival. Fui selecionada e parti para a localidade com a mente aberta, sem roteiros ou guias, mas, pautada por minhas concepções teóricas, portando, caneta e caderno para anotar tudo que me chamasse atenção, um celular sempre disponível para gravar áudio e/ou vídeo ou para fotografar o que chamasse a atenção e um notebook para digitar as notas de campo a cada dia. Como voluntária cheguei à localidade quatro dias antes do início do festival, fiquei hospedada nas dependências de uma escola existente na comunidade e fiquei mais um dia após a finalização do festival para uma reunião de feedback.

\section{BONS SONS ENQUANTO CAMPO EMPÍRICO}

O Bons Sons se define como um festival de música portuguesa que chama o público a viver a aldeia de Cem Soldos. Localizada na parte central de Portugal, Cem Soldos é uma 
comunidade rural pertencente à cidade de Tomar, na qual residem cerca de 600 habitantes. Durante os quatro dias de festival, a comunidade recebe mais de trinta mil pessoas, o que dá uma média de quase 10 mil pessoas por dia, capacidade máxima do local. Assim, o festival ocupa todos os espaços disponíveis na comunidade, cada casa, cada repartição pública, cada espaço de uso comum, ou seja, espaços privados e públicos se transformam para dar vida ao festival.

Como pode ser visto na figura 1, a aldeia é fechada para realização do festival e todo o recinto passa a ser Bons Sons. É tudo muito orgânico e a transformação acontece do dia para noite. Na noite da quinta-feira acontece a recepção ao campista e na manhã da sexta a aldeia é tomada por uma multidão ansiosa por vivenciar tudo que aquelas pessoas e aquele espaço podem oferecer. As cinco vias de acesso a Cem Soldos são fechadas e em quatro delas são postos pontos de entrada. A única via que fica fechada e não se constitui como entrada é a rua do pôr do sol, na qual fica o espaço criança e o posto de pronto socorro.

Quando me foi sugerido o Bons Sons eu achei que seria interessante estudar um festival que ocorre em um contexto rural, tem como foco na música local e se enfatiza questões ecológicas. A participação como voluntária me permitiu ter uma vivência muito além do que seria possível como festivaleira ou pesquisadora. Na medida em que me envolvia nas atividades de preparação da aldeia e que via um espaço rural comum se transformar em uma "pequena cidade" capaz de receber um festival de tamanha magnitude, fui percebendo que o festival e a comunidade se misturavam. Como um festival de quatro dias, realizado uma vez por ano, podia ter propiciado a manutenção de uma escola em funcionamento e criado um atelier de costura para as avós (senhoras da aldeia) que funciona o ano todo, foram questões que me inquietaram nos primeiros dias. Fui percebendo que a cada conversa emergiam projetos derivados do festival que não faziam sentido se vinculados apenas ao festival e ao questionar isso entendi que o festival, a associação e a comunidade estavam intrinsecamente imbricados. 
Figura 1 - Representação do Bons Sons no contexto da Aldeia de Cem Soldos

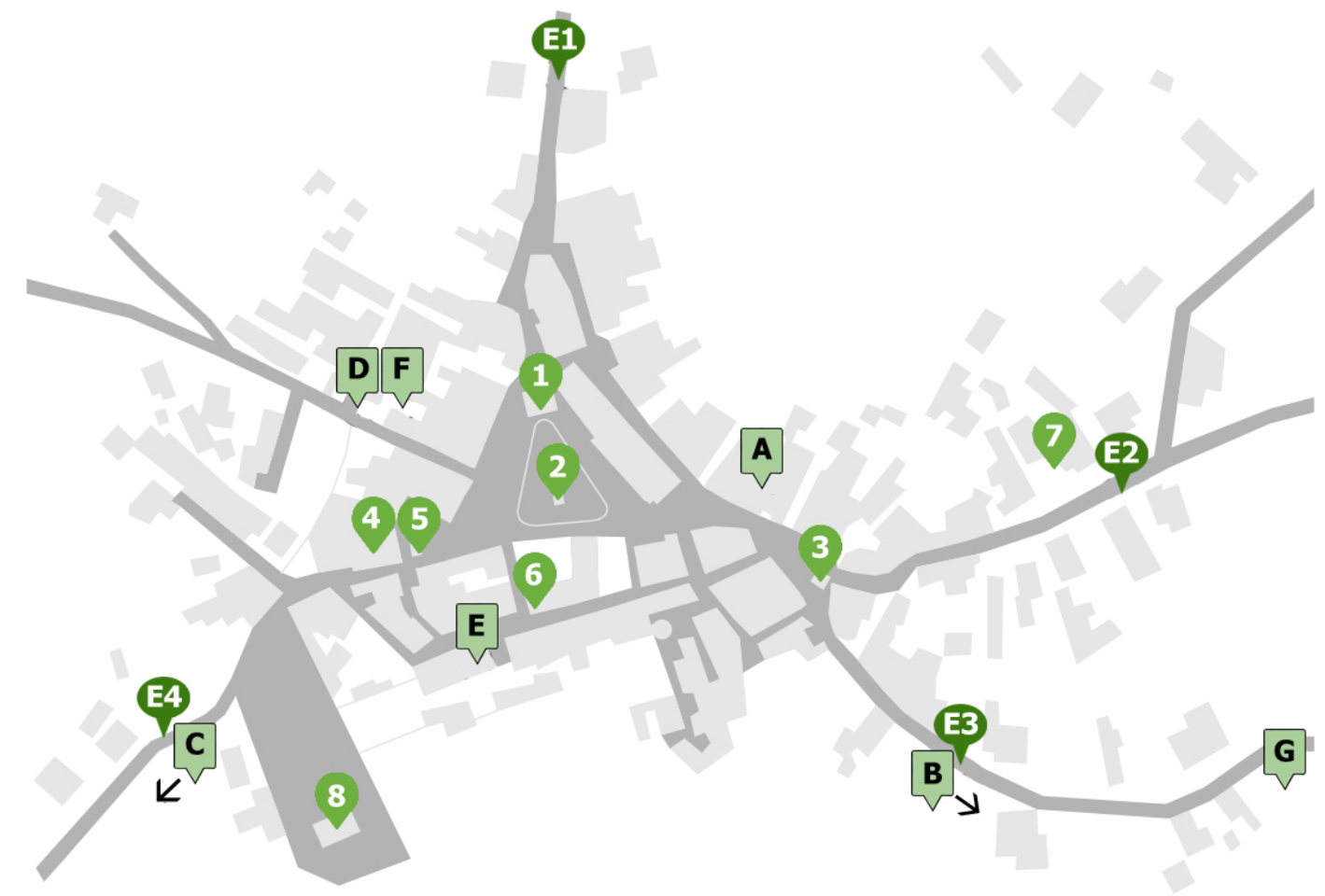

(1) Palco Lopes-Graça A Posto de Informação

2 Palco Aguardela

3 Palco Giacometti

4 Palco MPAGDP

5 Palco Tarde ao Sol

6 Garagem

7 Auditório

8 Palco Eira
B Parque de Campismo (acesso)

C Parque Caravanas (acesso)

D Posto Primeiros Socorros

E Armazém

F Espaço Criança

G Sleep'em'all
(F) Entrada Escola/ Rua da Escola

E2 Entrada Calçada/ Rua da Calçada

${ }^{E 3}$ Entrada Horta/ Rua dos Olheiros

E4 Entrada Igreja/ Estrada das Caldelas

Fonte: Adaptado de Bons Sons (2017).

A imersão em campo foi evidenciando que não era possível separar o festival da aldeia. Como expressou Tiago Pereira do projeto Música Portuguesa A Gosta Dela Própria (MPAGDP), o Bons Sons "não é o festival na aldeia, a aldeia é que é o festival” (RIOS, 2017, p.1), isto é, Cem Soldos se torna o Bons Sons e o Bons Sons é Cem Soldos. O festival colocou a aldeia no mapa, todos conhecem Cem Soldos pela dimensão que o festival tomou, sobretudo, no contexto de Portugal, mas que está tomando uma dimensão internacional. É interessante como todos são inseridos na comunidade como se fossem parte dela, as casas e as pessoas se abrem à multidão que vive o festival. Como expressou Shifter $(2017$, p. 1) "uma aldeia que dá para viver de tantas formas distintas por tantas pessoas diferentes, só pode ser 
descrita em conjunto". Então, falar do Bons Sons é falar de Cem Soldos e vice-versa e a conceituação do festival envolve múltiplas dimensões.

\section{CONSTRUÇÃO DO CORPUS}

Nas pesquisas de cunho quantitativo os pesquisadores precisam estabelecer critérios para selecionar uma amostra da população, os quais se baseiam em estatística e se bem delineados são representativos daquela população (BAUER; AARTS, 2002). Tal técnica é utilizada nas pesquisas sociais, contudo, ao estudar fenômenos sociais, muitas vezes não é viável ou desejável a quantificação. No caso dos estudos qualitativos, não se constitui amostra e sim corpus. O corpus é o conjunto de materiais: textos, imagens ou sons, representativos de determinada realidade, que o pesquisador escolhe para trabalhar (BARTHES, 1964). Tal escolha envolve certa arbitrariedade, pois os critérios são determinados por quem faz o estudo, mas deve ser pautada em construtos justificáveis (BAUER; AARTS, 2002).

Ten Have (2004) afirma que uma das formas de estruturar um estudo de natureza etnometodológica é utilizando estratégias de campo a fim de investigar situações cotidianas, nas quais a significação é compartilhada pelos atores envolvidos. No intento de ter um vislumbre da realidade possibilitando a interpretação das práticas dos agentes, sem que este processo seja impregnado por pressupostos apriorísticos, em estudos de natureza etnometodológica, são utilizados múltiplos métodos de obtenção de construtos.

Os instrumentos de coleta utilizados são os mesmos da etnografia, mas, as nuances objetivadas na coleta divergem em virtude da natureza da investigação. De acordo com Coulon (1995), os instrumentos de coleta utilizados em pesquisas que adotam a etnometodologia são: observação direta, observação participante, conversas informais e diálogos, gravações em vídeo, gravações de material pelos próprios atores, gravações de comentários sobre os fatos observados. São utilizados ainda fotos, documentos, notas de campo e entrevistas (RAWLS, 2008; TEN HAVE, 2004). Vale salientar que apesar de a entrevista ter despontado como sendo de uso natural em pesquisas qualitativas, nos estudos etnometodológicos esta não deve ser a fonte principal de dados devido à necessidade de acessar os sentidos atribuídos na realidade observada (TEN HAVE, 2004).

No estudo, em pauta, os construtos foram obtidos, principalmente, por meio de observação participante, conversas e diálogos informais, diários de campo, fotos e vídeos e entrevistas abertas, evitou-se entrevistas formalizadas, estas foram realizadas de modo informal e aberto, sem roteiro, no contexto em que as pessoas estavam atuando. Mas, também 
foram usadas informações de terceiros, advindas de materiais divulgados em jornais e revistas, de blogs e páginas pessoais vinculadas em domínio público, de sites e páginas oficiais do evento e de documentos de acesso restrito obtidos por intermédio dos membros de organização do evento. Na figura 2 é possível ver a composição do corpus deste estudo.

Figura 2 - Composição do Corpus

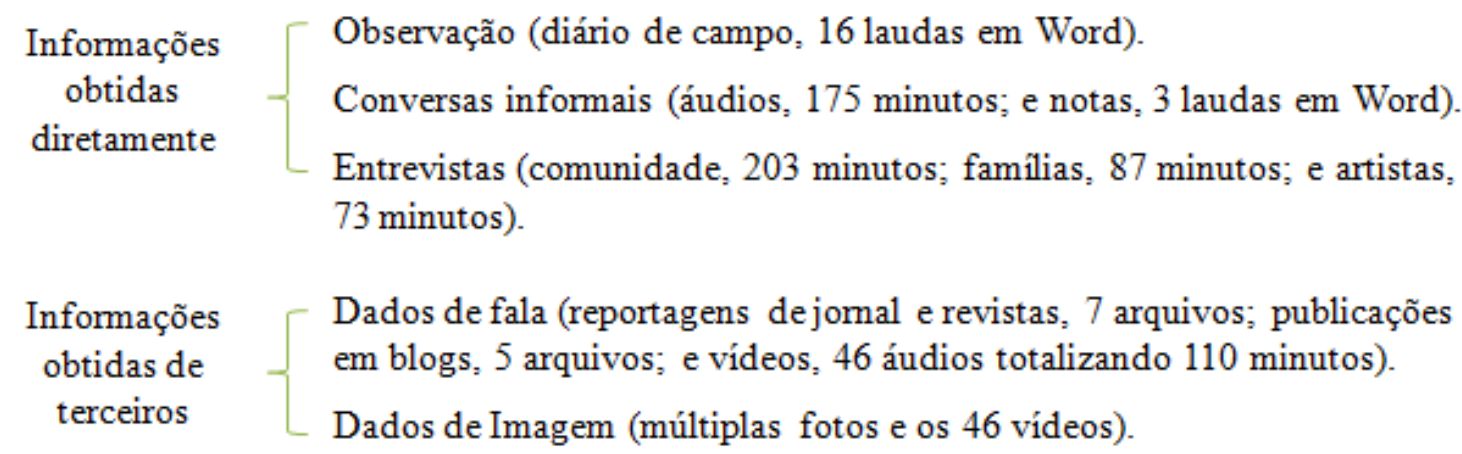

Fonte: Autoria (2020).

Todo esse processo de obtenção de construtos envolveu uma pessoalidade inerente aos estudos que lançam mão de técnicas oriundas dos estudos etnográficos. Neste tipo de pesquisa a imersão é parte fundamental do processo ao permitir o entendimento do cotidiano vivenciado. Nos oito que passei no local pude ver e viver a comunidade em sua totalidade; comi e bebi nos estabelecimentos existentes lá; conversei com moradores; fui à missa; fiquei sem internet, só acessava, rapidamente, uma ou duas vezes ao dia, o wifi de um café, o que foi bom porque não tinha distrações; e não me ausentei da comunidade em momento algum, portanto, foi um processo de imersão total. Tal vivência me permitiu acessar o universo estudado em sua face mais real. A principal base de obtenção de dados que compõe um corpus em estudos que se apropriam de instrumentos de coleta etnográficos é a observação participante (JOHNSTONE, 2000). É a partir da imersão no universo pesquisado que é possível identificar quem são atores que devem ser abordados, as temáticas a serem discutidas e os ambientes a serem observados.

Conforme Haguette (1992), a observação participante tem sua origem atribuída aos estudos da Antropologia iniciados com Malinowski e/ou da Escola Sociológica de Chicago. Ambos os campos se utilizaram de técnicas análogas ao abordar o objeto em estudo, sobretudo, "no valor que alocaram à participação do pesquisador no local pesquisado, e à necessidade de ver o mundo através dos olhos dos pesquisados". O que difere entre as abordagens é o foco de análise; enquanto a antropologia está preocupada em entender os sentidos das sociedades primitivas, a sociologia considera a sociedade em geral como um (c) $\left(\right.$ () $\mathrm{REAd}$ | Porto Alegre - Vol. 26 - N. ${ }^{\circ} 3$ - Setembro / Dezembro 2020 - p. 586-619. 
emaranhado de sentidos atribuídos ao longo das interações (HAGUETTE, 1992, p. 67). Tomando por base a sociologia interacional, entende-se, neste estudo, que as práticas se constituem a partir das interações que ocorrem em sites, contexto, no qual acontecimentos ou construções que compõem a vida social se processam (SCHATZKI, 2005), portanto, a observação participante surgiu como uma fonte substancial de dados.

O processo de observação ocorreu nos 8 (oito) dias de vivência na comunidade e se caracterizou como participante. A observação participante é "um processo no qual a presença do observador numa situação social é mantida para fins de observação científica. O observador está em relação face a face com os observados, e, ao participar da vida deles, coleta dados" (SCHWARTZ; SCHWARTZ, 1955, p.344). Além de viver intensamente as atividades da comunidade, nos preparativos, durante e, rapidamente, pós-festival, como observadora/pesquisadora, o fato de ser voluntária me tornava parte de tudo aquilo.

Durante o festival, busquei participar um pouco em cada espaço, fui em pelo menos uma atividade ou concerto em cada palco, vivenciei todos os horários do festival, estive pelo menos uma vez em cada espaço, desde a primeira atividade da manhã focada nas crianças até o último DJ do dia, passando pelos concertos nos diversos palcos, pelas visitas guiadas, pelos passeios de burros, pelo espaço criança, pelos jogos do Helder, entre outras atividades. Enquanto observadora/pesquisadora interagi com alguns artistas em entrevistas antes dos concertos; com as famílias e grávidas participantes da atividade denominada música para crianças, tanto durante a realização destas atividades quanto em entrevistas a posteriori; e com a comunidade, observando, refletindo, conversando, entrevistando e participando das atividades em geral.

A interação com a comunidade aconteceu de forma mais intensa nos dias que precederam o evento, pois quando o festival começou tudo se misturou e se transformou em um uníssono de pessoas com o mesmo interesse: viver aquele espaço. Mas, ainda era possível observar os moradores, em suas janelas, sobretudo as senhoras e em um dos bancos da praça, em geral os senhores, principalmente entre o meio e final da tarde. Também era possível interagir com o pessoal que trabalhava nos estabelecimentos comerciais existentes na comunidade.

Como observadora/pesquisadora e ao mesmo tempo voluntária, interagi com o pessoal do meu grupo de trabalho, o estudos de públicos, o qual foi responsável por aplicar questionários com o público, a fim de traçar o perfil deste. As interações ocorreram nas reuniões existentes, tanto antes quanto durante o festival, e nos momentos que nos 
encontrávamos no café ou na associação. Além disso, este grupo era supervisionado pela coordenadora de merchandising e pelo coordenador dos voluntários, os quais participaram da maioria das reuniões e com os quais conversei em muitas ocasiões.

Como voluntária, interagi com os demais voluntários a fim de nos conhecermos, dividirmos espaço e realizarmos os trabalhos de montagem do festival da melhor maneira possível. Estas interações aconteceram de forma mais intensa no pré-evento, pois as atividades eram mais coletivas. Durante o evento cada grupo estava envolvido com uma atividade específica. Antes do festival todos se reuniam e desempenhavam atividades colaborativas o que nos levou a interação e convívio. Em algumas ocasiões, alguns moradores se juntaram a nós para trabalhar e conversar. Na primeira noite, por exemplo, fiquei na mesa dobrando panfletos com um senhor que nos falou bastante sobre a vivência dele ali.

Ainda, como voluntária, interagi com o público em geral ao aplicar os questionários de estudo de público para a organização, o que aconteceu todos os quatro dias de festival. Apliquei 42 questionários com públicos diversos, entre 16 e 73 anos, homens e mulheres. Durante a aplicação, como o questionário tinha duas páginas e versava sobre muitos tópicos, as pessoas iam conversando e emitindo opiniões e nós interagíamos. O fato de eu ser brasileira, bastava que eu falasse uma palavra para eles perceberem, fazia com que a conversa fluísse, ou por eles quererem saber o que eu fazia ali, ou por me explicarem algo que eu não sabia, tem muitas palavras que são bem diferentes, então, foi um processo bem envolvente. Em quase todas as ocasiões que apliquei questionários o grupo acabou interagindo, em um caso específico acompanhei quatro pessoas até um dos restaurantes e ficamos conversando.

Conforme Baztán (1995) em estudos que usam instrumentos de coleta etnográficos a finalidade é fazer uma descrição sobre a comunidade em estudo, sendo o trabalho de campo, em particular, a observação participante, o processo e o relato, o produto deste processo. Por isso, manter um diário de campo detalhado e com as impressões pessoais é essencial neste tipo de estudo (VÍCTORA; KNAUTH; HASSEN, 2000). Desse modo, tudo que foi observado e conversado gerou o diário de campo, composto por todas as notas tomadas, durante esses dias. Como o ritmo foi muito intenso provavelmente coisas se perderam, mas o que chamava atenção era sempre anotado, o meu caderno e uma caneta estavam sempre a postos. Ao longo do dia, anotações eram feitas em cadernos e à noite estas eram digitadas e ganhavam mais comentários e reflexões.

Ladeira (2007) argumenta que a associação da observação participante com dados de fala tem sido profícua na geração de estudos mais robustos, pois existe uma 
complementaridade. A partir da observação do contexto é possível conhecer nuances e detalhes socioculturais da comunidade em estudo, o que permite a identificação dos atores que detêm informações acerca do fenômeno em estudo (CICOUREL, 1992). Neste momento é importante distinguir entre os informantes que emitem o discurso oficial e os que falam mais abertamente (BAZTÁN, 1995). Partindo, destas premissas, foram utilizadas, como instrumentos de coleta, conversas informais e entrevistas não estruturadas, as quais ocorreram durante os dias de imersão da comunidade, por conseguinte, concomitante com o processo de observação.

Entende-se como conversa "um espaço de formação, de troca de experiências, de confraternização, de desabafo" que "muda caminhos, forja opiniões [...]" (MOURA; LIMA, 2014, p. 99), portanto, não há a formalidade inerente às entrevistas. As pessoas estavam cientes do meu interesse em estudar aquela realidade e se mostraram curiosas, receptivas e até receosas, em alguns momentos. As conversas foram acontecendo de forma envolvente e orgânica, as pessoas queriam falar sobre o festival. Em alguns momentos não foi fácil porque todos estavam muito ocupados e cheios de atividades, mas todas as conversas ocorreram de forma leve e contributiva.

Algumas interações foram rápidas e geraram notas de campo, mas outras foram mais duradouras e geraram áudios que serviram como suporte à memória. Não são áudios formais, são gravações que foram usadas para que fosse possível relembrar fatos ao redigir as notas de campo. Para não expor os nomes das pessoas foram criados códigos para identificação dos participantes da pesquisa. Em algumas ocasiões, as pessoas me procuraram para contar algo, explicar um fato, dizer que eu devia falar com outra pessoa. As informações foram se encontrando e formando a estória sobre o festival e a comunidade e para meu registro foram incorporadas as notas de campo.

No que concerne às entrevistas entende-se que "a compreensão dos mundos da vida dos entrevistados e de grupos sociais especificados é a condição sine qua non da entrevista qualitativa". As entrevistas qualitativas podem ter "um fim em si mesmo" quando almejam fornecer "uma 'descrição detalhada' de um meio social específico" (GASKELL, 2002, p. 63). No estudo em questão, esta descrição era o foco devido à necessidade de conhecer o máximo sobre o festival e a interação deste com a comunidade. Por este motivo, optou-se pela entrevista não estruturada, aquela em que o entrevistado tem a prerrogativa de decidir sobre o que falar e como construir suas menções quanto à realidade discutida e em que o entrevistador tem a possibilidade de trazer os assuntos que achar convenientes para aquela interação 
(LAVILLE; DIONE, 1999). A ideia de não ter um roteiro foi permitir que as pessoas falassem de forma mais livre e escolhessem o que enfatizar ao abordar o festival e a comunidade.

Não se pretendeu com este processo alcançar uma objetividade, as escolhas da temática e dos atores foram imbuídas de subjetividade. Mas, porque, dentro daquele universo de pessoas, escolher esta e não aquela? O que pautou a minha escolha pelos atores foi o conceito de sustentabilidade adotado no âmbito deste estudo e, claro, as minhas vivências e conhecimentos anteriores. Nas conversas informais, alguns temas foram me chamando atenção, guiada por estas questões, fui direcionada às pessoas que poderiam falar sobre estes aspectos em específico.

Apesar de não lançar mão de um roteiro preestabelecido era necessário ter algo que norteasse a realização da entrevista e eu optei pelos preceitos estabelecidos por Flick (2002, p. 117) ao discorrer sobre entrevista episódica. Desse modo, as pessoas foram convidadas a falar sobre o festival de forma geral e sobre alguns aspectos ou questões específicas que haviam me chamado a atenção pela observação ou pelas conversas informais. Eu busquei mencionar situações concretas e cotidianas da comunidade em geral e deixar os participantes livres para escolher sua forma de resposta. As entrevistas ocorreram em meio à organização ou realização do festival e foram realizadas no ambiente de atuação dos atores, ou seja, nos locais onde os atores estavam desempenhando suas funções no festival. No caso da coordenação do grupo das avós e do padre fui recebida em suas casas, tendo em vista que suas funções são desenvolvidas ao longo do ano e não na estruturação física do festival.

Além dos membros da comunidade, foram entrevistadas 11 (onze) famílias enfocando na inclusão de atividades para as crianças no âmbito do festival e 6 (seis) com artistas enfatizando o sentimento deles em serem parte do festival. As entrevistas com as famílias ocorreram após alguma das sessões de música para crianças. Uma delas foi bastante interessante por envolver duas famílias cujos pais eram voluntários na organização do festival e falaram sobre assuntos diversos, além das atividades para crianças. Não houve um critério determinante para selecionar as famílias, se elas estivessem no música para crianças, ao final da sessão, eram chamadas a participar da pesquisa, o único critério que se colocou foi haver famílias que estavam indo pela primeira vez e que já haviam participado em edições anteriores das atividades voltadas para crianças. As entrevistas com os artistas ocorreram no backstage do palco em que eles iriam fazer o concerto, elas foram agendadas pela assessoria de comunicação. Buscou-se acessar um artista de cada palco, assim, os entrevistados atuaram 
em palcos diferentes. Tal critério visou à diversificação dos participantes, visto que em cada palco predominava um estilo diferente.

Um fator a ser levado em consideração quando são realizadas entrevistas é a necessidade de transcrição. Em estudos etnometodológicos não se almeja descrever o conteúdo das falas, ou seja, o texto, mas sim a significação e entendimentos dos membros de um grupo. Desse modo, é muito mais interessante ouvir várias vezes o áudio da entrevista de modo a remeter ao contexto fazendo anotações e notas do que analisar pura e simplesmente o conteúdo transcrito (TEN HAVE, 2004). Desse modo, os áudios das entrevistas geraram várias notas (39 laudas em Word) decorrentes das repetidas audições realizadas para fins de análise e interpretação de entendimentos.

Além de informações obtidas diretamente, um conjunto de informações obtidas de terceiros foi incorporado para composição do corpus deste estudo. Em termos de dados de fala têm-se entrevistas do diretor do festival; reportagens e matérias de jornais e revistas; publicações em blogs e comunidades; e vídeos. No que concerne aos dados de imagem, não se teve a intenção de analisá-los em si, mas de utilizá-los como material de apoio às análises provindas dos dados de fala. A ideia de usar imagem é importante porque "a imagem, com ou sem acompanhamento de som, oferece um registro restrito, mas poderoso das ações temporais e dos acontecimentos reais" (LOIZOS, 2002, p.137). Sendo assim, imagens dos vídeos analisados e fotos próprias, das reportagens ou da página do festival no Facebook (https://www.facebook.com/bonssons/) foram usadas para fornecer uma visualização do que se retratava.

Salientamos que a obtenção das informações, sobretudo as acessadas diretamente, seguiram os padrões de ética em pesquisa, a pesquisadora foi apresentada a toda a comunidade, na reunião de recepção dos voluntários, como sendo alguém que estaria ali para realizar uma pesquisa e a informação foi disseminada, fato expresso pelas inúmeras abordagens sendo chamada de 'a senhora do doutorado'. Além disso, em todas as interações que geraram áudios gravados foi usado do termo de consentimento livre e esclarecido e nas demais interações sempre se discutia o objetivo da presença da pesquisadora ali, até porque este fato gerava curiosidade na maioria das pessoas.

\section{INTERPRETAÇÃO DOS CONSTRUTOS}

Em estudos de natureza qualitativa geralmente surgem muitas informações para interpretação. Tendo em vista que o processo de coleta etnometodológico é aberto, sendo 
utilizadas múltiplas estratégias e fontes de dados, em geral, o pesquisador se depara com uma infinidade de informações. No meu caso não foi diferente, devido às múltiplas formas de acesso a dados e à extensão do corpus, emergiram muitas informações, o que, a priori, me deixou "perdida" em um mar de informações desconectadas, que muito explicavam a realidade, mas que não constituíam uma construção narrativa internamente coerente.

O que o etnometodólogo enfrenta "é uma multiplicidade de estruturas conceituais complexas, muitas delas sobrepostas ou amarradas umas às outras, que são simultaneamente estranhas, irregulares e inexplícitas, e que ele tem que, de alguma forma, primeiro apreender e depois apresentar” (GEERTZ, 2008, p.7). O pesquisador, ao buscar interpretar como os membros de um grupo atribuem significado ás atividades, constituindo, assim, as práticas, vai se deparar com muitas informações, as quais podem estar desordenadas e entrelaçadas. Portanto, se faz necessário buscar entender quais as estruturas conceituais mais adequadas, evidenciar quais são os alicerces destas e proceder à interpretação do modo como estas são estabelecidas pelos atores.

Diante deste cenário é necessário criar meios para proceder análises, categorizações e interpretações. Não existem regras consolidadas quanto à forma de execução deste processo de análise em estudos pautados por etnométodos, sendo válida qualquer forma de apreciação que vise acessar o fenômeno, desde que os pressupostos desta abordagem sejam respeitados (TEN HAVE, 2004). O ponto fundamental é que o pesquisador consiga compartilhar os significados e sentidos atribuídos pelos atores estudados (BISPO; GODOY, 2012). Este será o balizador da interpretação dos construtos.

Tendo com finalidade subsidiar a análise e posterior interpretação dos dados, optou-se por usar os principais conceitos da etnometodologia a fim de gerar um protocolo para a análise de dados. Para tanto, tomou-se como base um quadro proposto por Bispo e Godoy (2014, p. 129) com a finalidade de explicitar como cada um destes conceitos (práticas/realizações, indexicalidade, reflexividade, relatabilidade e noção de membro) contribui no processo de análise e interpretação dos dados. A concepção do protocolo foi uma adaptação da proposta de Bispo e Godoy (2014) para o estudo, sendo os conceitos gerados a partir da interpretação dos conceitos teóricos trabalhados anteriormente, conforme figura 3.

Figura 3 - Protocolo para análise dos dados

\begin{tabular}{l|l|l|} 
Conceito & Descrição teórica do conceito & Perguntas norteadoras da análise \\
$\begin{array}{l}\text { Realizações/ } \\
\text { Práticas }\end{array}$ & $\begin{array}{l}\text { As ordens sociais são constituídas } \\
\text { pelas realizações práticas de uma } \\
\text { coletividade, portanto, para }\end{array}$ & $\begin{array}{l}\text { As práticas identificadas representam } \\
\text { o cotidiano da comunidade* estudada } \\
\text { e são reconhecidas pelos seus }\end{array}$
\end{tabular}

(c) $(1) \Theta$ REAd | Porto Alegre - Vol. 26 - N. ${ }^{\circ} 3$ - Setembro / Dezembro 2020 - p. 586-619. 


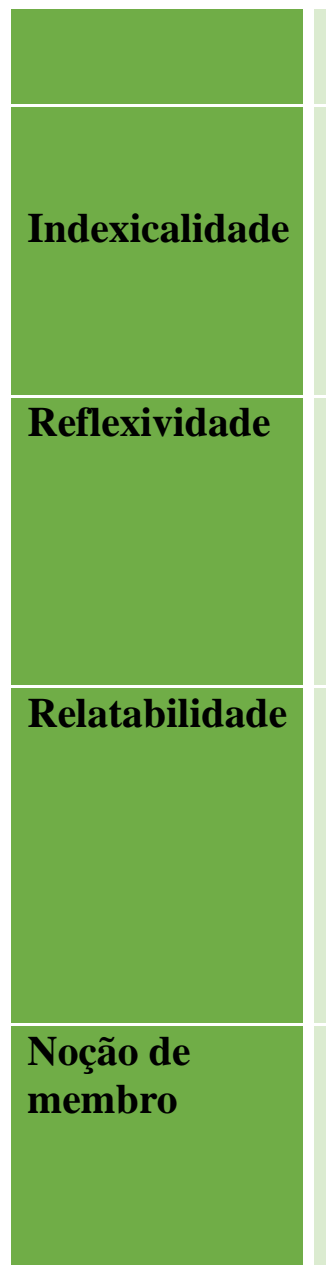

entender uma realidade é necessário fazer parte dela.

Os entendimentos são influenciados não apenas pelos enunciados, mas também pelo contexto de fala. As palavras podem significar múltiplas coisas, devendo ser entendidas a partir do seu contexto de fala.

Interpretações contextuais balizam as interações sociais. As ações geram reações e estas são decorrentes dos processos de significação nas interações sociais, que podem gerar novas práticas.

As realizações práticas devem ser relatadas de modo que as ordens sociais sejam compreendidas. Para interpretar as atividades práticas de uma coletividade é preciso entender como estas são descritas pelos membros do grupo.

membros como próprias e características desta?

O conjunto de práticas identificadas apresentam uma linguagem própria da comunidade investigada? Os sentidos atribuídos expressam os sentidos vivenciados pelos membros dessa comunidade?

As práticas identificadas criam ao longo do tempo condições de perpetuação, modificação ou geração de novas práticas que passam a ser reconhecidas pelos membros como resultado do seu cotidiano?

Como as práticas são descritas e quais são os sentidos e significados atribuídos pelos membros da comunidade estudada as ações realizadas? O que conduz a realização das atividades de tal forma e não de outra?

As pessoas compõem as práticas, não por se organizarem coletivamente, mas por usarem uma linguagem comum que permite a compreensão mútua.

O conjunto de práticas mapeadas permite ao pesquisador identificar claramente quem são os indivíduos que são efetivamente da comunidade e não apenas "estão" nela?

Fonte: Adaptado de Bispo e Godoy (2014).

*O conceito comunidade foi usado, no escopo deste trabalho, como uma representação de "Bons Sons enquanto expressão de Cem Soldos".

O protocolo permite que as análises sejam pautadas em um roteiro e propicia maior confiabilidade a geração das informações, mas todo este processo é marcado pelo método documentário. Tal conceito alçado por Garfinkel exprime que os seres humanos não dão contam de todos os entendimentos e sentidos existentes em suas interações por isso nós lançamos mão de um sistema interpretativo que visa preencher as lacunas oriundas da indexicalidade da linguagem. Assim, a coleta, as análises e interpretações de dados foram desenvolvidas tendo por base os meus entendimentos acerca das interações vivenciadas. Ten Have (2004) argumenta que as investigações que têm por base a etnometodologia devem ser desenvolvidas em duas etapas. A primeira diz respeito à interpretação dos significados atribuídos pelos atores as práticas e a segunda a análise das estratégias utilizadas pelo pesquisador para realizar tal interpretação.

Conforme Geertz (2008) se o intento é compreender um fenômeno não é suficiente olhar para teorias ou descobertas sobre o mesmo nem tampouco para o que os especialistas

REAd | Porto Alegre - Vol. 26 - N. ${ }^{\circ} 3$ - Setembro / Dezembro 2020 - p. 586-619. 
proferem sobre ele. Os esforços devem ser concentrados em entender o que os praticantes do fenômeno fazem. Assim, o foco de análise é o entendimento dos significados atribuídos pelos atores às práticas. No entanto, a forma de interpretação na busca deste entendimento também é parte do estudo, pois o pesquisador é componente do contexto estudado e, portanto, está imbuído de significações que influenciam o processo de compreensão dos sentidos conferidos pelos atores as práticas. Neste contexto, a autorreflexão é uma parte essencial na análise de dados em estudos etnometodológicos.

A base que fundamenta a concepção de autorreflexão é o fato de o pesquisador ao mesmo tempo em que investiga o mundo social é uma parte constituinte e constituída neste, ou seja, ele desenvolve sua pesquisa em um espaço do qual ele é mesmo é um componente (FRANCIS; HESTER, 2004). A autorreflexão "é um processo em que o pesquisador pode “decantar" as informações e experiências obtidas em campo para que seja possível, após algum tempo, uma melhor condição de avaliar e compreender as práticas que são buscadas em campo" (BISPO; GODOY, 2014, p. 126).

Os indivíduos são dotados de conhecimentos e experiências que os permitem analisar as situações vividas, desse modo, a autorreflexão viabiliza a análise dos fenômenos em estudo, tendo como balizador os entendimentos do pesquisador acerca do mundo social investigado. A autorreflexão permite o estabelecimento de um diálogo com as experiências vivenciadas no processo de pesquisa (TEN HAVE, 2004) o que permite a geração de conexões e padrões que coaduna em uma construção narrativa coerente. Após a imersão no campo, é necessário manter um distanciamento da realidade estudada (FLORES-PEREIRA; CAVEDON, 2008) a fim de refletir sobre o que foi vivenciado e assim decantar os dados em informações, ou seja, gerar os resultados a partir das análises do corpus, neste caso em forma de construções narrativas - as práticas.

A fim de gerar as práticas e categorizá-las os dados foram analisados de forma exploratória interpretativa. Os áudios foram ouvidos repetitivamente. Na primeira vez não foram geradas notas, na segunda foram gerados relatos e até foram transcritas as partes que mais chamaram atenção. As notas de campo foram lidas e relidas diversas vezes. Além disso, foram geradas notas com relatos e transcrições de algumas passagens das reportagens e postagens e dos vídeos que compuseram o corpus deste estudo, os quais também foram revisitados muitas vezes. Estas leituras e escutas constituíram a fase exploratória dos dados. Partindo desta base, os áudios foram ouvidos repetidas vezes e as notas relidas buscando embasar as práticas que emergiram a partir de um processo interpretativo. Todo esse processo 
foi mediado e pautado pelo protocolo de análise e gerou nove práticas subsidiadas por múltiplas interpretações advindas de variadas fontes de informações.

Como os estudos de natureza etnometodológica visam interpretar o cotidiano, o cerne da análise deve ser o entendimento das minúcias envoltas na forma de atuação dos atores estudados, isto é, o ponto neural é a capacidade de realizar interpretações que expressem os significados compartilhados pelos atores investigados. Coulon (1995, p. 93) afirma que "um traço essencial da prática etnometodológica é que ela requer a descrição”. O fruto de um estudo pautado por esta perspectiva é a exposição dos relatos das práticas estudadas evidenciando como estas foram construídas, apreendidas e compartilhadas, bem como, como elas se transformam ao longo do tempo (BISPO; GODOY, 2012). Desse modo, no estudo em questão, tomou-se por base o protocolo proposto e gerou-se práticas a partir do modelo (material, competência e significado) proposto por Shove, Pantzar e Watson (2012), as quais foram categorizadas conforme o conceito de sustentabilidade em ambientais, econômicas ou sociais.

\section{CONSIDERAÇÕES FINAIS}

Algumas considerações precisam ser estabelecidas acerca do uso da etnometodologia enquanto método de pesquisa aplicado em estudos na área de administração e estes últimos parágrafos se destinam a isso. Uma questão fundamental neste tipo de investigação é o estabelecimento de uma conexão com o local e com as pessoas, não estamos advogando que devem ser criados laços baseados em julgamentos e concepções, mas que é necessário ter um vínculo que permita sentir o que está se passando. Conforme Fuentes (1990, p. 1) a proposta etnometodológica de Garfinkel "procura compreender a situação social 'de dentro', tal como aparece aos indivíduos que a vivem; trata de transmitir o sentido que eles têm das coisas". Sob este prisma os indivíduos tomam por base o senso comum e ao interpretá-lo atuam construindo e reconstruindo a realidade, e, por conseguinte, o mundo social. Neste sentido, "para aproximar-se da realidade [...] a pesquisa em ciências sociais deve atentar para o conhecimento do senso comum e para as razões práticas dos sujeitos no mundo social" (OLIVEIRA; MONTENEGRO, 2012, p. 133). Atentar para isso é particularmente importante nos estudos em ciências sociais aplicadas, sobretudo, administração, pois, neste campo se trabalha com casos que explicam realidades que são distintas e difíceis de serem replicadas.

Para os etnometodólogos "o saber não se constrói com observações imparciais, fora do contexto do objeto de estudo, mas é na interação com o meio, na busca por compartilhar o 
sentido, que o significado das práticas para a construção de uma interpretação coletiva da realidade se dá" (BISPO; GODOY, 2012, p. 695). Isso nos leva a outra questão, é importante vivenciar o ambiente de forma intensa, seja em termos de tempo ou densidade da imersão. Antes de empreender este estudo havia uma preocupação em termos de tempo. Eu acreditava que para realizar um estudo etnometodológico seria necessário um longo período de tempo em imersão no contexto estudado e após a inserção na comunidade eu entendi que não era apenas uma questão de tempo, a intensidade também influenciava neste processo. Apesar de ter sido uma imersão de uma semana seguida de mais algumas semanas de pesquisas a respeito de materiais secundários na internet a vivência foi tão intensa que a quantidade de informações era imensa e havia saturação destas. Desse modo é fundamental imergir profundamente no contexto estudado, mas não é necessariamente o espaço temporal que determinam esta profundidade, claro que o tempo continua sendo expressivo e importante, contudo, faz se necessário atentar para intensidade. Esse processo vai depender do objeto em estudo, do objetivo, das condições de aproximação do campo, das relações estabelecidas, do que se almeja entender e observar, dentre outros fatores.

Isso nos remete a questão da imparcialidade do pesquisador ao realizar a pesquisa. É importante salientar que não é possível ser imparcial ao fazer interpretações da realidade o que se frisa aqui é a não estruturação de modelos e concepções. Nos estudos em administração é comum à criação de modelos que ajudam na visualização e aplicação de teorias, temos a tendência de estruturar as informações em gráficos, quadros e figuras, o que é muito válido em muitos estudos. Entretanto, em estudos etnometodológicos esta estruturação não é o foco, a ideia é interpretar o cotidiano e não enquadrá-lo em um modelo. Isso começa no processo de construção do corpus, instrumentos de coleta de dados estruturados vão de encontro à proposta etnometodológica. Isso não quer dizer que a pesquisa é feita sem nenhum embasamento, na verdade, as interações são guiadas pelas as suas intenções, por mais que não haja um roteiro, existe uma visão de mundo e um arcabouço teórico que norteiam o desenvolvimento do estudo. São as experiências pessoais que guiam a forma como nos posicionamos e não temos como nos livrar delas durante a pesquisa, portanto, é preciso entender que elas norteiam a imersão.

No processo de imersão é preciso estar disponível para ouvir porque muitas conversas que surgem, sem serem programadas, podem trazer informações ricas para o entendimento daquela realidade. É importante mostrar interesse no objeto a fim de que as pessoas te falem sobre, todavia, é preciso estabelecer limites para são ser invasivo. Como os estudos 
etnometodológicos envolvem o cotidiano se tornam muito pessoais e se as pessoas se sentem invadidas tendem a se fechar e controlar as informações que detém. Por isso é preciso ter bastante cuidado durante as interações. Em muitos momentos é melhor recuar se houver alguma indicação de constrangimento ou de resistência, mesmo que você perceba que algo importante está sendo omitido. Em outras interações esta informação pode vir à tona ou você pode mudar de foco, o que é preferível a ter informações distorcidas ou a gerar uma desconfiança nos atores estudados. É válido ter em mente que as pessoas não são obrigadas a exporem opiniões e pensamentos sobre algo, caso não se sintam a vontade, o pesquisador acaba sendo um "intruso" e precisa estar atento para recuar quando sentir que está sendo inconveniente de algum modo.

Um aspecto que me parece ser determinante é a questão da transparência de intenção. Deixar claro o que você almeja mostrar às pessoas quais são seus propósitos e as deixar livre para escolher colaborar ou não. Mesmo que parte da sua pesquisa tenha que ser suprimida é preciso esclarecer que aquela interação vai ser usada em uma pesquisa, exceto no caso de conversas muito informais em que os envolvidos não serão diretamente parte do seu segmento empírico ou que sejam informações de terceiros já disponíveis para acesso público. Do ponto de vista ético é fundamental se pautar pelos princípios da boa conduta em pesquisa. Usar termos de consentimento livre e esclarecido, explicitar objetivos e deixar claro que nomes não serão expostos, sem a devida autorização. Se alguém se sentir ludibriado poderá resultar na quebra de confiança, o que poderá inviabilizar a realização da pesquisa, além de ser eticamente questionável.

Além disso, a aceitação de membros da comunidade é fundamental para abrir portas. Identificar pessoas chave, que não só possam dar informações, mas também, indicar outras pessoas, fornecendo contatos ou mediando esta interação, ajuda muito no estabelecimento de uma relação de confiança. É muito mais fácil chegar a um pesquisado com a indicação de alguém ou sendo apresentado por um conhecido dele do que como alguém que ele não sabe nada sobre. Esse foi um fato que ficou evidente no desenvolver dessa pesquisa, apesar de a comunidade ser inclusiva, eu era uma desconhecida e ser introduzida por pessoas de lá facilitava muito o processo e gerava aceitação. As primeiras tentativas de contato com algumas pessoas foram frustradas, até que houve a legitimação do contato via membros da comunidade e as portas se abriram.

A seguir, na figura 4 , trazemos um quadro resumo dos principais pontos a serem levados em consideração na construção de uma investigação usando como método a 
etnometodologia.

Figura 4 - Principais Pontos para Construção de uma Investigação Etnometodológica

\begin{tabular}{ll}
\hline $\begin{array}{l}\text { Investigações } \\
\text { Etnometodológicas }\end{array}$ & $\begin{array}{l}\text { Fornecem explicações para contextos situados, ou seja, cenários } \\
\text { socioculturais específicos nos quais se processam interações } \\
\text { gerando significados. }\end{array}$ \\
\hline $\begin{array}{l}\text { Indiferença } \\
\text { Etnometodológica }\end{array}$ & $\begin{array}{l}\text { Os etnometodólogos devem conduzir suas investigações sem pré- } \\
\text { concepções, tendo em vista o alcance do entendimento do cerne das } \\
\text { práticas cotidianas, isto é, de como elas realmente são construídas, bem } \\
\text { como, de qual significação é atribuída às mesmas. }\end{array}$ \\
Estruturação & $\begin{array}{l}\text { Apesar de muitos estudos apresentarem etapas a serem cumpridas, } \\
\text { quando nos propomos a realizar um estudo lançando mão de princípios } \\
\text { etnográficos, em geral, não é possível desenvolver a investigação de }\end{array}$ \\
maneira linear. Algumas concepções podem surgir antes da imersão e \\
outras só tempos depois da saída de campo. É um jogo constante e \\
aproximação e distanciamento (CLIFFORD, 2002). Não é possível \\
seguir uma estrutura linear com passos e roteiros. \\
Eampo \\
$\begin{array}{l}\text { É importante entender qual a realidade antes da imersão, mas evitando } \\
\text { conceber análises de qualquer natureza, não se indica a concepção de }\end{array}$ \\
instrumentos, roteiros ou questões estruturadas que possam ditar o \\
caminho. Indica-se que o processo de imersão seja tão orgânico quanto \\
possível e que os atores envoltos ditem o ritmo da investigação.
\end{tabular}

Postura do

Pesquisador
Apesar de haver a necessidade de aproximação vívida para com o campo empírico e, por conseguinte, com os atores envoltos, buscando significar as interpretações deles sobre a realidade, é fundamental que se deixe claro que as interações fazem parte de uma investigação científica, tanto por questões éticas quanto pela necessidade de estabelecer relações de confiança.

A imersão é parte fundamental do processo ao permitir o entendimento Corpus do cotidiano vivenciado. Tal vivência me permitiu acessar o universo estudado em sua face mais real. É importante estar atenta e aberta a obter informações diversas e até não esperadas. Entrevistas podem ser realizadas, sendo preferível que sejam abertas e não constituam a principal fonte de informações.

Interação

Estar aberta a criar vínculos de interação, demonstrar interesse em entender a vivencia dos atores, buscar pontos que os façam ter motivos para interagir são pontos chave no processo. Se as pessoas não quiserem falar sobre algo não adiantará forçar e talvez seja melhor mudar o foco, a ideia é que elas sejam as interessadas em falar.

Formação de Construtos
Os construtos precisam seguir alguma forma de estrutura e por isso há uma necessidade de ter alguma forma de protocolo para formação destes, uma ideia é seguir os conceitos chave da etnometodologia, como eu fiz, tendo em vista que ela é teoria e método. Além disso, se faz necessário ter uma lente teórica para basilar essa formação de construtos, exceto se a própria etnometodologia for usada, também, 
com este fim. No caso em estudo utilizamos como lente teórica as teorias da prática e sustentabilidade.

O campo de estudos em Administração é muito amplo e diverso e não teria como ser diferente tendo como objeto de estudo as organizações. Devido à diversidade e multiplicidade de formas organizacionais e de formas de interação entre estas e a sociedade em geral, sejam em nível individual ou coletivo, lançar mão de métodos que nos permitam acessar interpretações sobre as interações em contextos situados pode contribuir para avanços no campo. Nesse sentido, entendemos que a etnometodologia abre espaço para observarmos as organizações sob a ótica do cotidiano e isso pode trazer novas informações sobre os fenômenos organizacionais.

\section{REFERÊNCIAS}

ANTONACOPOULO, E. P. The Relationship between Individual and Organizational Learning: New Evidence from Managerial Learning Practices. Management Learning, Vol. 37(4), p. 455-473, Dec. 2006.

BARTHES, R. Éléments de Sémiologie. In: Communications, 4, 1964. Recherches sémiologiques. pp. 91-135. Disponível em: <http://www.persee.fr/doc/comm_05888018_1964_num_4_1_1029> Acesso em: 22 de Maio de 2017.

BAUER, M. W.; AARTS, B. A Construção do Corpus: Um Princípio para a Coleta de Dados Qualitativos. In: BAUER, M. W.; GASKELL, G. Pesquisa qualitativa com texto: imagem e sam: urn manual prático. Tradução de Pedrinho A. Guareschi. Petrópolis: Vozes, 2002. BAZTÁN, A. A. Etnografia: metodología cualitativa en la investigación sociocultural. Barcelona: Marcombo, 1995.

BERGER, P. L.; LUCKMANN, T. The social construction of reality. New York: Doubleday, 1967.

BISPO, M. de S.; GODOY, A. S. A Etnometodologia enquanto Caminho Teóricometodológico para a investigação da Aprendizagem nas Organizações. Revista de Administração Contemporânea, v.16, n.5, p. 684-704, 2012.

BISPO, M. de S.; GODOY, A. S. Etnometodologia: uma proposta para pesquisa em estudos organizacionais. Revista de Administração da UNIMEP. 2014, v. 12, n. 2, maio/ago. 
BONS SONS. Recinto. 2017. Disponível em: <http://www.bonssons.com/recinto/>. Acesso em: 26 de Outubro de 2017.

BROWN, J. S.; DUGUID, P. Organizational learning and communities-of-practice: toward a unified view of working, learning, and innovation. Organization Science, v. 2, n. 1, February, p. 40-57, 1991.

CANDY, P. Understanding the individual nature of learning. In: Self direction

for lifelong learning: a comprehensive guide to theory and practice. San Francisco: JosseyBass, 1991. Cap. 8, p. 249-278.

CHAPPELLS, H.; MEDD, W.; SHOVE, E. Disruption and change: drought and the inconspicuous dynamics of garden lives. Social \& Cultural Geography, 2013, 12:7, 701715.

CICOUREL, A. The interpenetration of communicative contexts: example from medical encounters. In: GOODWIN, C.; DURANTI, A. Rethinking context. Cambridge: Cambridge University Press, 1992.

CLIFFORD, J. A experiência etnográfica: antropologia e literatura no século XX. 2. ed. Rio de Janeiro: Editora UFRJ, 2002.

COULON, A. Etnometodologia. Tradução de Ephraim Ferreira Alves. Petrópolis: Vozes, 1995.

EASTERBY-SMITH, M.; ARAUJO, L. Aprendizagem Organizacional: oportunidades e debates atuais. IN: EASTERBY-SMITH, M.; BURGOYNE, J.; ARAUJO, L. Aprendizagem Organizacional e Organização de Aprendizagem: desenvolvimento na teoria e na prática. São Paulo: Atlas, 2001.

EASTERBY-SMITH, M.; CROSSAN, M.; NICOLINI, D. Organizational Learning: Debates Past, Present and Future. Journal of Management Studies. September, 2000.

EASTERBY-SMITH, M.; SNELL, R.; GHERARDI, S. Organizational learning: diverging communities of practice. Management Learning, v. 29, n. 3, p. 259-272, 1998.

ELKJAER, B. Organizational learning: the 'third way'. Management Learning, v. 35, n. 4, p. 419-434, December, 2004.

ELKJAER, B. Pragmatism: a learning theory for the future. In: ILLERIS, K. Contemporary Theories of Learning. New York: Taylor \& Francis Routledge, 2009. Cap. 5, p. 74-89. FENWICK, T. Experiential Learning: A Theoretical Critique from Five Perspectives. Information Series No. 385. ERIC Clearinghouse on Adult, career, and Vocational Education, Columbus, on. Office of Educational Research and Improvement (ED), Washington, DC.

(c) (1) $\left(\right.$ REAd | Porto Alegre - Vol. 26 - N. ${ }^{\circ} 3$ - Setembro / Dezembro 2020 - p. 586-619. 
2001.

FENWICK, T. Understanding Relations of Individual - Collective Learning in Work: A Review of Research. Management Learning, v. 39, n 3, p. 227-243, 2008.

FLICK, U. Entrevista episódica. In: BAUER, M. W.; GASKELL, G. Pesquisa qualitativa com texto: imagem e sam: urn manual prático. Tradução de Pedrinho A. Guareschi. Petrópolis: Vozes, 2002.

FLORES-PEREIRA, M. T.; CAVEDON, N. R. Os bastidores de um estudo etnográfico: trilhando os caminhos teórico-empíricos para desvendar as culturas organizacionais de uma livraria de shopping center. Cadernos EBAPE.BR, v. 7, $\mathrm{n}^{\circ}$ 1, artigo 10, Rio de Janeiro, Mar. 2009.

FUENTES, G. A. Harold Garfinkel: la etnometodología. Revista de Sociología, [S.1.], n. 5, ene. 1990. Disponível em:

<http://www.revistadesociologia.uchile.cl/index.php/RDS/article/view/27606/29273>. Acesso em: 10 de fevereiro de 2016.

FRANCIS, D.; HESTER, S. An Invitation to Ethnomethodology: language, society and interaction. London: Sage, 2004.

GARFINKEL, H. Estudios en Etnometodología. Traduccíon de Hugo Antonio Pérez Hernáiz. Barcelona: Anthropos, 2006.

GASKELL, G. Entrevistas Individuais e Grupais. In: BAUER, M. W.; GASKELL, G. Pesquisa qualitativa com texto: imagem e sam: urn manual prático. Tradução de Pedrinho A. Guareschi. Petrópolis: Vozes, 2002.

GEERTZ, C. A Interpretação das Culturas. $1^{\mathrm{a}}$ ed. $13^{\mathrm{a}}$ reimpressão. Rio de Janeiro: LTC, 2008.

GHERARDI, S.; NICOLINI, D.; ODELLA, F. Toward a social understanding of how people learn in organizations. Management Learning, v. 29, n. 3, p. 273-297, 1998.

GIDDENS, A. A constituição da sociedade. 3. ed. São Paulo: Martins Fontes, 2009.

GUESSER, A. H. A etnometodologia e a análise da conversação e da fala. Revista Eletrônica dos Pós-Graduandos em Sociologia Política da UFSC; Vol. 1 nº 1 (1), agostodezembro/2003, p. 149-168.

HAGUETTE, T. M. F. Metodologias qualitativas na sociologia. 4. ed. Petrópolis: Vozes, 1992.

HERITAGE, J. Etnometodologia. In: GIDDENS, A.; TURNER, J. (Org.). Teoria social hoje. São Paulo: Editora UNESP, p. 321-392, 1999.

(c) (1) @ REAd | Porto Alegre - Vol. 26 - N. ${ }^{\circ} 3$ - Setembro / Dezembro 2020 - p. 586-619. 
JARZABKOWSKI, P.; SPEE, A. P. Strategy-as-practice: a review and future directions for the field. International Journal of Management Reviews, v. 11, p. 69-95, 2009.

JOHNSON, G.; LANGLEY, A.; MELIN, L.; WHITTINGTON, R. Introducing the strategy as practice perspective. In: Strategy as practice: research directions and resources.

Cambridge: Cambridge University Press. p. 3-27, Cap. 1, 2007.

JOHNSTONE, B. Qualitative methods in sociolinguistics. New York: Oxford University Press, 2000.

JULES-ROSETTE, B. Harold Garfinkel: la contribution de l'ethnomethodologie à la recherche sociologique. Sociétés: Revue des sciences humaines et sociales, 1985, vol. 5, p. $35-38$.

KOTTAK, C. P. Antropologia: una exploración de la diversidad humana. Madrid: McGrawHill, 1997.

KOTTER, J. O que os gerentes gerais eficazes realmente fazem. In: Afinal, o que fazem os líderes: a nova face do poder e da estratégia. Rio de Janeiro: Campus, 2000. Cap. 7 , p. $126-151$.

LADEIRA, W. T. Teoria e Métodos de Pesquisa Qualitativa em Sociolinguística Interacional. Revista de Ciências Humanas, Vol. 7, Nº 1, p. 43-56, Jan./Jun. 2007.

LAVE, J.; WENGER, E. Situated learning: legitimate peripheral participation. Cambridge, UK: Cambridge University Press, 1991.

LAVILLE, C.; DIONNE, J. A construção do saber: manual de metodologia da pesquisa em ciências humanas. Porto Alegre: Artes Médicas; Belo Horizonte: UFMG, 1999.

LOIZOS, P. Vídeo, Filme e Fotografias como Documentos de Pesquisa. In: BAUER, M. W.; GASKELL, G. Pesquisa qualitativa com texto: imagem e sam: urn manual prático. Tradução de Pedrinho A. Guareschi. Petrópolis: Vozes, 2002.

MAYO, E. The Human Problems of an Industrial Civilization. New York: The Macmillan Company, 1933.

MERRIAM, S.; CAFFARELLA, R.; BAUMGARTNER, L. Traditional learning theories. In: Learning in adulthood: a comprehensive guide. San Francisco: Jossey-Bass. 3. ed. 2007. Cap. 11, p. 275-297.

MEZIROW, J. Making meaning: the dynamics of learning. In: Transformative dimensions of adult learning. San Francisco: Jossey-Bass, 1991. Understanding transformation theory. Adult Education Quarterly, v. 44, n. 4, p. 222-232, Summer, 1994. 
MIETTINEN, R. The concept of experiential learning and John Dewey's theory of reflective thought and action. International Journal of Lifelong Education, v. 19, n. 1, p. 54-72, Jan./Feb., 2000.

MINTZBERG, H. Trabalho do executivo: o folclore e o fato. In: Coleção Harvard de Administração. São Paulo: Nova Cultural, 1986. v. 3, p. 5-37.

MOURA, A. F.; LIMA, M. G. A Reinvenção da Roda: Roda de Conversa: Um Instrumento Metodológico Possível. Revista Temas em Educação, João Pessoa, v.23, n.1, p. 98-106, jan.jun. 2014.

OLIVEIRA, S. A. de, MONTENEGRO, L. M. Etnometodologia: Desvelando a Alquimia da Vivência Cotidiana. Cadernos EBAPE, v. 10, n. 1, p.129-145, 2012.

RAWLS, A. W. Harold Garfinkel, Ethnomethodology and Workplace Studies. Organization Studies, v. 29, n. 05, p.701-732, 2008.

RIOS, P. O Bons Sons “não é o festival na aldeia, a aldeia é que é o festival”. Público, 13 de Agosto de 2017. Disponível em: <https://www.publico.pt/2017/08/13/culturaipsilon/noticia/obons-sons-nao-e-o-festival-na-aldeia-a-aldeia-e-que-e-o-festival-1782235> Acesso em: 20 de agosto de 2017.

SCHWARTZ, M. S.; SCHWARTZ, C.G. Problems in participant observation. American Journal of Sociology, 60, p. 343-354, 1955.

SCHATZKI, T. R.; CETINA, K. K; SAVIGNY, E. V. The practice turn in contemporary theory. London: Routledge, 2001.

SHOVE, E. Beyond the ABC: climate change policy and theories of social change.

Environment and Planning A, 42, $\mathrm{n}^{\circ}$ 6, 2010.

SCHATZKI, T. R. The sites of organizations. Organization Studies, v. 26, n. 3, p. 465-84, 2005.

SHIFTER. Mais que um festival de verão, o Bons Sons é um convite a viver a aldeia de Cem Soldos. 30 de Agosto de 2017. Disponível em: <https://shifter.pt/2017/08/bons-sons2017/> Acesso em: 30 de Agosto de 2017.

SHOVE, E. The shadowy side of innovation: unmaking and sustainability. Technology

Analysis \& Strategic Management, 2012, 24:4, 363-375.

SHOVE, E. Putting practice into policy: reconfiguring questions of consumption and climate change. Journal of the Academy of Social Sciences, 2012a.

SHOVE, E. Habits and Their Creatures. In: WARDE, A.; SOUTHERTON, D. The habits of consumption. Helsinki: Collegium, 2012b, Vol. 12, p. 100-113.

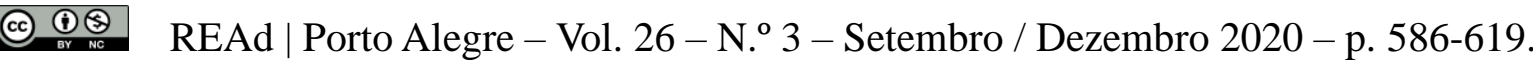


SHOVE, E.; PANTZAR, M.; WATSON, M. The Dynamics of Social Practice: Everyday life and how it changes. London: Sage, 2012.

SILVA, V. G. D. O antropólogo e sua magia. São Paulo: Edusp, 2000.

SPORT CLUB OPERÁRIO DE CEM SOLDOS - SCOCS. Página do Youtube. Disponível em: <https://www.youtube.com/channel/UCflMSHWckL-Uib81kLhw1eA>. Acesso em: 26 de fevereiro de 2019.

TEN HAVE, P. Understanding Qualitative Research and Ethnomethodology. London:

Sage, 2004.

VÍCTORA, C.; KNAUTH, D.; HASSEN, M. Pesquisa qualitativa em saúde: uma introdução ao tema. Porto Alegre: Tomo, 2000.

WHITTINGTON, R. Strategy as practice. Long Range Planning, v. 29, n. 5, 731-735, 1996. 